\title{
A Corpus-Based Study of Two Former American Presidents'
}

\section{Inaugural Addresses}

\author{
Dr. Maosheng Hung* \\ Associate professor, Department of English, School of Foreign Languages, Fuzhou University of International \\ Studies and Trade, Fuzhou, PR China
}

\begin{abstract}
*Corresponding Authors: Dr. Maosheng Hung, Associate professor, Department of English, School of Foreign Languages, Fuzhou University of International Studies and Trade, Fuzhou, PR China
\end{abstract}

\begin{abstract}
This study aimed to investigate how two former American presidents 'language tendencies in speech and their personalities were related and how their word choice revealed their personality traits. A total of four inaugural speeches given by Bill Clinton and George W. Bush (two by Clinton, and two by Bush) during their presidency were collected and examined via a set of corpus running software called WordSmith Tools 5.0. The analyses and comparisons conducted on the collected data showed that Clinton was more concrete and positive, talked more to the audience/nation, and censored himself more; Bush was more personal, formal, distant, aggressive, pointed, social, dynamic, detailed, specific, and paid more attention to the future.
\end{abstract}

Keywords: American, address, corpus, inaugural, personality, president

\section{INTRODUCTION}

\subsection{Corpus}

According to Hunston (2002), the term corpus is defined by its form and purpose. Linguists usually use this word to describe a collection of naturally occurring language instances. The scope of this collection can be from several sentences to written articles or recordings that are mainly collected for language research. However, this term has recently been used to represent a collection of articles that can be stored and retrieved through a computer. Because computers can store and process a large amount of information, the capacity of an electronic corpus is usually larger than that of a paper corpus that was previously used to study language elements. In addition, a corpus is generally designed for the purpose of studying a certain language. And this specific purpose determines the choice of articles placed in the corpus. Different from libraries or electronic resources, a corpus is not set up to store articles or books.

\subsection{Characteristics of Using Corpora For Analysis}

Biber, Conrad, and Reppen (1998) stated several main characteristics of using corpora for analysis: 
(1) It can analyze the actual patterns of language use in natural texts.

(2) It uses a huge and regular integration of natural articles (i.e., corpus) as the basis for analysis

(3) It uses computers extensively for analysis.

(4) It relies on both quantitative and qualitative analysis skills.

The advantages of several of these analysis methods actually come from the use of computers because computers can find and analyze complex language usage patterns, store and parse larger natural language databases, and these cannot be handled by hand. In addition, computers can also perform consistent and reliable analysis of data because they do not change their minds or cause burnout at any time like humans. However, although reliance on computers can generate a lot of quantitative data, in order to explore the importance of research findings for understanding the form of language use, the use of corpora for analysis still needs to qualitatively explain the data.

\subsection{What Analysis can be done With a Corpus?}

In fact, a corpus itself cannot do anything except for storing the language being used or being studied. However, if the corpus is sufficiently representative and can be combined with computer software, it can help us make many different observations on the use of language. Generally speaking, such combination can at least reveal (1) the frequency of the vocabulary, (2) the grammatical structure of the vocabulary, and (3) the word(s) or phrase(s) that a word is often used with (Hunston, 2002).

\section{(1) The frequency of vocabulary (Frequency)}

The words in a corpus can be arranged by computer software in the order of their frequency of appearance in the corpus. The following example is part of the data from a high-frequency vocabulary reference book Hung and Hung (2012) wrote for a publishing company. The content of the book is based on the researchers' past collection of test questions of two major college entrance examinations in Taiwan (i.e., the General Scholastic Ability Test (GSAT) and the Advanced Subjects Test (AST)) and written up via a set of corpus analysis software, WordSmith Tool 5.0.It can be seen from Table 1 that the definite article the appears 3,727 times in the 21 tests, ranking first among all other words, followed by to (1,914 times), of (1,717 times), in (1,387 times), and (1,321 times), is (864 times). In addition, among the top 50 words that appear most frequently in these tests, most of them are so-called function words (including prepositions, pronouns, conjunctions, question words... etc.). Only a few of the wordsarecontent words. The above observations and comparisons can all be shown by running out the frequency of words in the corpus.

Table1. The Top 50 Words that Appear Most Frequently in the GSAT and AST

\begin{tabular}{|l|l|l|}
\hline $\mathbf{N}$ & Word & Freq. \\
\hline 1 & the & 3,727 \\
\hline 2 & to & 1,914 \\
\hline 3 & of & 1,717 \\
\hline 4 & in & 1,387 \\
\hline
\end{tabular}


A Corpus-Based Study of Two Former American Presidents' Inaugural Addresses

\begin{tabular}{|c|c|c|}
\hline 5 & and & 1,321 \\
\hline 6 & is & 864 \\
\hline 7 & for & 659 \\
\hline 8 & that & 547 \\
\hline 9 & are & 482 \\
\hline 10 & it & 454 \\
\hline 11 & they & 413 \\
\hline 12 & as & 385 \\
\hline 13 & on & 373 \\
\hline 14 & with & 365 \\
\hline 15 & I & 361 \\
\hline 16 & was & 358 \\
\hline 17 & their & 344 \\
\hline 18 & be & 329 \\
\hline 19 & have & 290 \\
\hline 20 & from & 280 \\
\hline 21 & by & 267 \\
\hline 22 & not & 258 \\
\hline 23 & he & 249 \\
\hline 24 & can & 238 \\
\hline 25 & more & 234 \\
\hline 26 & this & 230 \\
\hline 27 & his & 227 \\
\hline 28 & you & 222 \\
\hline 29 & at & 221 \\
\hline 30 & has & 217 \\
\hline 31 & people & 214 \\
\hline 32 & what & 203 \\
\hline 33 & which & 203 \\
\hline 34 & or & 197 \\
\hline 35 & when & 197 \\
\hline 36 & an & 182 \\
\hline 37 & one & 182 \\
\hline 38 & were & 179 \\
\hline 39 & than & 178 \\
\hline 40 & about & 169 \\
\hline 41 & but & 169 \\
\hline 42 & she & 157 \\
\hline 43 & all & 155 \\
\hline
\end{tabular}


A Corpus-Based Study of Two Former American Presidents' Inaugural Addresses

\begin{tabular}{|c|c|c|}
\hline 44 & will & 146 \\
\hline 45 & many & 143 \\
\hline 46 & most & 143 \\
\hline 47 & new & 138 \\
\hline 48 & her & 137 \\
\hline 49 & had & 133 \\
\hline 50 & we & 130 \\
\hline
\end{tabular}

\section{(2) Grammatical structure of vocabulary (Phraseology)}

By using software (i.e., concordancing program) that can find the rules of vocabulary use, the grammatical structure of vocabulary can also be summarized from the corpus. Take for example the data collected in the vocabulary reference book compiled by Hung and Hung (2012) for Taiwanese senior high school students planning to enter universities (see the following Table $2 \&$ Table 3). The concordance function in WordSmith Tools 5.0was used to extract all the sentences containing a/an (Due to space limitations, only 15 sentences were extracted each.) to understand the differences in the language use of the two articles. From the observation and comparison of the two tables, the following generalizations can be found and made: the appearance of the article an must be followed by a word beginning with a vowel, and the distribution of the article $a$ is complementary to that of $a n$. In addition to this example, the same software can also be used to compare and contrast the grammatical structures of words with the same meaning in the corpus (such as interesting/interested) or to find out the different patterns that the same word may have (such as walk, walked, walks, walking... ).

Table2. The Sentences Containing $a$ in the Corpus of the GSAT and AST

\begin{tabular}{|l|l|}
\hline $\mathbf{N}$ & Concordance \\
\hline 1 & $\begin{array}{l}\text { ated to be kept under full control. (C) Learn to Lighten Up and Live Longer is a popular book. (D) Stress is } \\
\text { always more positive than harmful to the body. }\end{array}$ \\
\hline 2 & $\begin{array}{l}\text { According to the passage, which of following is a positive effect of stress? (A) Watching funny movies. (B) } \\
\text { Doing relaxing exercise. (C) Avoiding difficult t }\end{array}$ \\
\hline 3 & $\begin{array}{l}\text { n, they are lightly rolled and left in a fermentation room to develop scent and a red color. Next, they are heated } \\
\text { several more times. Finally, the leaves are d }\end{array}$ \\
\hline 4 & $\begin{array}{l}\text { y are heated several more times. Finally, the leaves are dried in a basket over a charcoal fire. Green tea leaves } \\
\text { are heated in steam, rolled, and dried. Oolong }\end{array}$ \\
\hline 5 & $\begin{array}{l}\text { he mind and body work together to produce stress, which is a bodily response to a stimulus, a response that } \\
\text { disturbs the body's normal physiological balance. H }\end{array}$ \\
\hline 6 & $\begin{array}{l}\text { na heart attack. The mind and body work together to produce stress, which is a bodily response to a stimulus, } \\
\text { a response that disturbs the body's normal phy }\end{array}$ \\
\hline 7 & $\begin{array}{l}\text { body work together to produce stress, which is a bodily response to a stimulus, a response that disturbs the } \\
\text { body's normal physiological balance. However, stre }\end{array}$ \\
\hline 8 & $\begin{array}{l}\text { ee-quarters of American high school juniors said they felt stress at least once a week, some almost daily. } \\
\text { Fewer than half of Japanese and Taiwanese eleventh gr }\end{array}$ \\
\hline 9 & \begin{tabular}{l} 
ing. Conversely, worry can give a person an ulcer, high blood pressure, or even a heart attack. The mind and \\
\hline
\end{tabular} \\
\hline
\end{tabular}




\begin{tabular}{|l|l|}
\hline 10 & body work together to produce stress, which is \\
\hline 11 & $\begin{array}{l}\text { er, stress is not always bad. For example, a stress reaction can sometimes save a person's life by releasing } \\
\text { hormones that enable a person to react quickly and } \\
\text { problem. (C) spiritual healing. (D) physiologic }\end{array}$ \\
\hline 12 & $\begin{array}{l}\text { asing hormones that enable a person to react quickly and with greater energy in a dangerous situation. In } \\
\text { everyday situations, too, stress can provide that extr }\end{array}$ \\
\hline 13 & $\begin{array}{l}\text { reaction can sometimes save a person's life by releasing hormones that enable a person to react quickly and } \\
\text { with greater energy in a dangerous situation. In e }\end{array}$ \\
\hline 14 & $\begin{array}{l}\text { rea for both languages. People who learned a second language later in life used a special part of Broca's area } \\
\text { for their second language, near the one activate }\end{array}$ \\
\hline 15 & $\begin{array}{l}\text { y breathe in a space suit. 52. A parachute needs to be opened because it can (A) slow down the shuttle. (B) stop } \\
\text { the shuttle from falling. (C) make the shutt }\end{array}$ \\
\hline
\end{tabular}

Table3. The Sentences Containing an in the Corpus of the GSAT and AST

\begin{tabular}{|c|c|}
\hline $\mathbf{N}$ & e \\
\hline 1 & $\begin{array}{l}\text { leaves and leaf buds on a clear sunny day and letting the leaves dry for about an hour in the sun. Then, they ar } \\
\text { lightly rolled and left in a fermentation roo }\end{array}$ \\
\hline 2 & $\begin{array}{l}\text { arts of the brain when learning a second language. He used an instrument called an MRI (magnetic resonanc } \\
\text { imaging) to study the brains of two groups of bilingu }\end{array}$ \\
\hline 3 & $\begin{array}{l}\text { movies can reduce pain and promote healing. Conversely, worry can give a person an ulcer, high bloo } \\
\text { pressure, or even a heart attack. The mind and body work }\end{array}$ \\
\hline 4 & $\begin{array}{l}\text { 7. I had to __ Jack's invitation to the party because it conflicted with an important business meeting } \\
\text { (A) decline (B) depart (C) devote (D) deserve } 8\end{array}$ \\
\hline 5 & $\begin{array}{l}\text { anger, who perform an } 21 \text { act in a difficult situation, and heroes who live an ordinary life like us, who d } \\
\text { their work } 22 \text { by many of us, but who } 23\end{array}$ \\
\hline 6 & $\begin{array}{l}\text { at hunting (B) was good at disguising (C) had beautiful skins and paws (D) was an enemy to the white man }{ }^{2} \dot{A} \\
53 \text { 'Ü } 56 \tilde{\mathrm{A} D} \neg^{\circ} \tilde{\mathrm{A}} \mathrm{D}^{2} \mathrm{O} \text { Recently, Dr. Stuart Campbell o }\end{array}$ \\
\hline 7 & $\begin{array}{l}\text { f the gray wolf (D) appreciated the gray wolf's hunting skills } 51 \text {. What was an important reason for the fas } \\
\text { disappearance of the wolf? (A) The wolf could }\end{array}$ \\
\hline 8 & $\begin{array}{l}\text { ed state-of-the-art 3-D/4-D scanning services to expectant parents. He performs an average of } 30 \text { scans a week } \\
\text { His outspoken enthusiasm for this blessed technol }\end{array}$ \\
\hline 9 & $\begin{array}{l}\text { and some with disappointment. 55. Which of the following people is most likely an anti-abortionist? (A) Ann } \\
\text { Carp. (B) Geoff Brodie. (C) Stuart Campbell. }\end{array}$ \\
\hline 10 & $\begin{array}{l}\text { over a woman's right to choice. After all, nothing can be more persuasive than an unborn child's beaming face } \\
53 \text {. What is the author's attitude toward a }\end{array}$ \\
\hline 11 & $\begin{array}{l}\text { every two American marriages ending in divorce, custody of children has become an issue in the American } \\
\text { society. Up until the late } 1970 \text { s, it had been common pr }\end{array}$ \\
\hline 12 & $\begin{array}{l}\text { B) integrity (C) intimacy (D) ingenuity } 6 . \text { The discovery of the new vaccine is an important } \\
\text { fight against avian flu. (A) breakthrough (B) commi }\end{array}$ \\
\hline
\end{tabular}




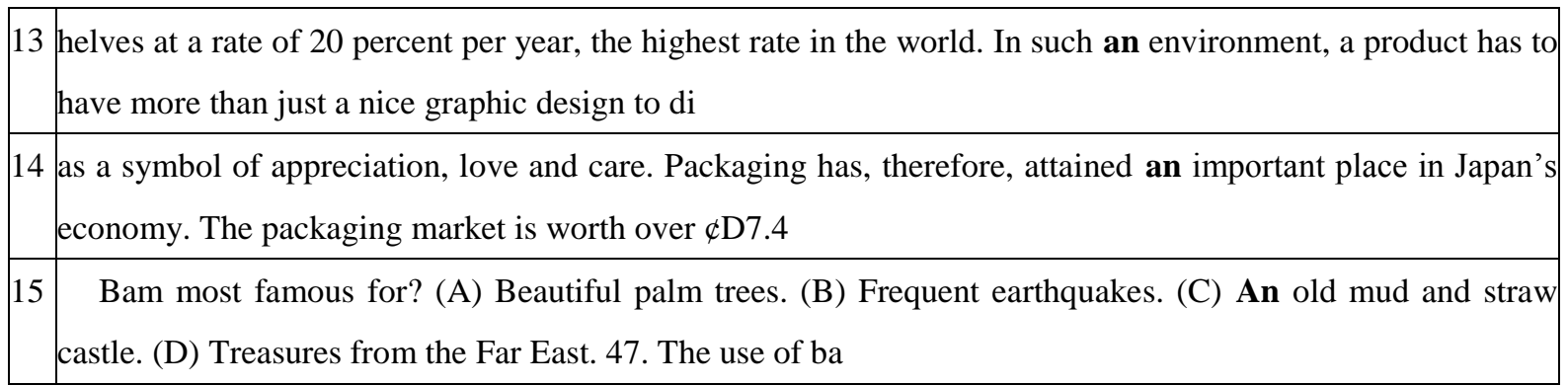

\section{(3) A group of two or more words that usually go together (Collocation)}

Collocation refers to the tendency of two or more words to occur together frequently. It can be often seen in all kinds of languages. However, to measure it more reliably in a statistical way, it must be aided by corpus and computer.

The following Table 4 is an example extracted from the corpus built by Hung and Hung (2012) for their vocabulary reference book. From this example, it can be concluded that the English word related most often occurs with the preposition to and "be" verbs in the questions of the GSAT and the AST in the past 10 years. The preposition to always appears in the right side of related and is right next to it. The "be" verbare, in contrast, appears on the left side of related. However, if we want to further confirm whether related is also used in conjunction with to in other contexts or just in general use, we need a larger and more complete corpus that covers the contexts or general conditions for conducting inductive analysis to obtain results.

Table4. An Example Extracted from the Corpus Built by Hung and Hung (2012) for Their Vocabulary Reference Book

\begin{tabular}{|c|c|c|}
\hline$N \mathrm{C}$ & Concordance & Set Ta! \\
\hline 1 & REJOICING RELATE RELATED RELATING RELATION & \\
\hline 2 & i@17i@ twenty-five non-medically related technological innovations that & \\
\hline 3 & time for. (A) appealed to (B) took to (C) related to (D) saw to 15 . Why do we & \\
\hline 4 & physician office visits are for stress-related illnesses and complaints. Stress & \\
\hline 5 & to follow because they were ___ related to the topic under discussion. (A) & \\
\hline 6 & DS REFER REFUSED RELATED RELAXRELEASHNG & \\
\hline 7 & REJECTING REJOLCING RELATED RELATING RELATIVE & \\
\hline 8 & poems on his paintings are often not related to objects in the real world. (D) & \\
\hline 9 & stresses, his creations are closely related to his unique personal history. & \\
\hline 10 & Greek word for curls and locks is related to intriguing and tempting & \\
\hline 11 & (D) Our reaction to pain is closely related to our expectation of pain. 54 . & \\
\hline 12 & of my subconscious emotions were related to my relationship with my father. & \\
\hline 13 & instance, heat stress and other heat-related health problems are caused & \\
\hline 14 & mummies, both of which are closely related to Egyptian religious beliefs. The & \\
\hline
\end{tabular}

\subsection{The Application of Corpora}

A corpus can be used in a wide range. In addition to the research on ideology, culture, translation, stylistics and compilation of grammar books and dictionaries, the most common application of corpora is in language teaching (Hunston, 2002). Usually, the application of a corpus in language teaching is nothing more than two levels. One is that through the establishment and analysis of the corpus, teachers summarize the language characteristics they want to teach and students must learn. For example: in order to be successful in the business field in the future, students from the department 
of business must be very familiar with English business terms that are often used in international trade. At this time, their teachers can help students find these vocabulary and terms through the concept of corpora, followed by organizing and introducing them to students systematically. The second level is to allow students to interact with a corpus. Through their own establishment and use of the corpus, they can classify the knowledge they want to learn and then enhance their self-learning. However, this level of application needs to have enough computer equipment in the language class roomso that students can learn by themselves effectively (Schmitt, 2010).

Based on the aforementioned description and introduction, it seems that corpora have seldom been used to explore the relationship between politician's language tendencies in speech and their personalities. Hence, the current study attempted to investigate how two former American presidents' language tendencies in speech and their personalities were related and how their word choice revealed their personality traits by focusing on their inaugural addresses during their presidency.

\section{METHODS}

This study was conducted by analyzing and comparing the inaugural speeches of two former American presidents, Bill Clinton and George W. Bush. The research design was composed of three stages of research process. The first stage was to construct a specialized corpus of inaugural addresses for each of the presidents. The second stage was to elicit the top 100 frequently occurring wordsineach corpus. The last stage was to compare the top 100 words of these two corpora and see how these words were consistent with their peronalities.

\subsection{Instrument}

This study used a corpus-based approach with WordSmith Tools 5.0 as its instrument. Basically, WordSmith Tools 5.Oincludes three text analysis tools: a monolingual concordancer (Concord) and wordlist extractors (WordList and KeyWords). The integrated suite of programs can process .html, .xml and .txt files. The WordList tool lets usersobtain a list of all the words or word-clusters in a text, arranged in alphabetical or frequency order. The concordancer, Concord, allowsusers a chance to see anyword or phrase in context -- so that they can see what type of company it keeps.With KeyWords users can find the key words in a text. From the introduction of the main function of the three tools, the WordList tool is to demonstrate word frequencies. Therefore, the WordList tool aided in discovering the most frequent words from the collected inaugural addresses of the two former American presidents (i.e., Bill Clinton and George W. Bush) in the current research.

\subsection{Corpora Construction}

The collected two inaugural speeches of Bill Clinton were delivered on Jan. 20, 1993 and Jan. 20, 1997 respectively. They were built as a corpus, and the corpus contained a total of 3,779 tokens. As for the two collected inaugural addresses of George W. Bush, they were made on Jan. 20, 2001 and Jan. 20, 2005 respectively. The speeches were built as another corpus, which included 3,670 tokens. All of the four inaugural speeches were acquired from the website of Miller US Presidential Research Center of University of Virginia.

\subsection{Data Analysis}

This project proceeded in four steps. These steps were carried out by using WordSmith Tools 5.0. For 
the first step, all data of Bill Clinton's and George W. Bush's inaugural addresses were collected and made in MS-Word documents (.doc). The second step was to convert the MS-Word documents into plain text files (.txt) respectively with WordSmith Tools 5.0. In the third step, from the plain text files, WordSmith Tools 5.0 generated a word frequency list for each corpus via the tool of WordList. The results showed the most frequent words in an ordered list for each corpus. Right after that, in the fourth step, based on the word frequency lists, the top100 frequently occurring words from each corpus were manually elicited, analyzed and compared.

\section{RESUlts}

\subsection{The Most Frequent 100 Words in the Corpus of Clinton's Inaugural Speeches}

In an attempt to analyze the corpus of Bill Clinton's inaugural addresses, the current study initially sought the most frequent 100 words via the WordList tool of WordSmith Tools 5.0 program. The raw data of the top 100 frequent words in the corpus of Clinton's inaugural speeches is displayed in Table 5. As can be seen in Table 5, the word the reoccurred the most often. It was used as a function word and had the highest ranking with 131 occurrences. The other most frequently occurring words were and, our, to, and of. Also, a word that fits into the category of content word, that is, the word form of "be" verb is, ranked as the $9^{\text {th }}$ most occurring word.

Table5. The Word Frequency List of Bill Clinton's Inaugural Addresses (1 100)

\begin{tabular}{|c|c|c|c|c|c|c|c|c|c|c|c|}
\hline Rank & Word & Freq. & Rank & Word & Freq. & Rank & Word & Freq. & Rank & Word & Freq. \\
\hline 1 & the & 131 & 26 & it & 13 & 51 & I & 7 & 76 & once & 4 \\
\hline 2 & and & 91 & 27 & this & 13 & 52 & more & 7 & 77 & promise & 4 \\
\hline 3 & our & 74 & 28 & Americans & 12 & 53 & no & 7 & 78 & renew & 4 \\
\hline 4 & to & 69 & 29 & century & 12 & 54 & work & 7 & 79 & renewal & 4 \\
\hline 5 & of & 64 & 30 & time & 12 & 55 & across & 6 & 80 & revolution & 4 \\
\hline 6 & we & 63 & 31 & today & 12 & 56 & own & 6 & 81 & season & 4 \\
\hline 7 & in & 41 & 32 & let & 11 & 57 & American & 5 & 82 & service & 4 \\
\hline 8 & $\mathrm{a}$ & 39 & 33 & when & 11 & 58 & as & 5 & 83 & still & 4 \\
\hline 9 & is & 33 & 34 & who & 11 & 59 & democracy & 5 & 84 & their & 4 \\
\hline 10 & for & 25 & 35 & so & 10 & 60 & done & 5 & 85 & there & 4 \\
\hline 11 & world & 25 & 36 & an & 9 & 61 & each & 5 & 86 & way & 4 \\
\hline 12 & America & 22 & 37 & change & 9 & 62 & great & 5 & 87 & whom & 4 \\
\hline 13 & have & 21 & 38 & nation & 9 & 63 & idea & 5 & 88 & your & 4 \\
\hline 14 & must & 20 & 39 & what & 9 & 64 & millions & 5 & 89 & bold & 3 \\
\hline 15 & us & 19 & 40 & at & 8 & 65 & on & 5 & 90 & cannot & 3 \\
\hline 16 & are & 18 & 41 & be & 8 & 66 & those & 5 & 91 & capital & 3 \\
\hline 17 & that & 18 & 42 & do & 8 & 67 & again & 4 & 92 & celebrate & 3 \\
\hline 18 & but & 16 & 43 & my & 8 & 68 & been & 4 & 93 & children & 3 \\
\hline 19 & with & 16 & 44 & now & 8 & 69 & better & 4 & 94 & civil & 3 \\
\hline 20 & by & 15 & 45 & will & 8 & 70 & challenges & 4 & 95 & communities & 3 \\
\hline
\end{tabular}


A Corpus-Based Study of Two Former American Presidents' Inaugural Addresses

\begin{tabular}{|l|l|l|l|l|l|l|l|l|l|l|l|}
\hline 21 & new & 15 & 46 & you & 8 & 71 & citizens & 4 & 96 & congress & 3 \\
\hline 22 & not & 15 & 47 & can & 7 & 72 & economy & 4 & 97 & edge & 3 \\
\hline 23 & all & 14 & 48 & fellow & 7 & 73 & generation & 4 & 98 & every & 3 \\
\hline 24 & people & 14 & 49 & government & 7 & 74 & less & 4 & 99 & families & 3 \\
\hline 25 & from & 13 & 50 & has & 7 & 75 & make & 4 & 100 & free & 3 \\
\hline
\end{tabular}

\subsection{The Most Frequent 100 Words in the Corpus of Bush's Inaugural Speeches}

By using the WordList tool of WordSmith Tools 5.0 software, the frequency list of the top 100 frequent words used in the corpus of George W. Bush's inaugural addresses can be seen in Table 6. The top five words used were function words, and they included the(142 times), which was utilized generally as a determiner. Moreover, of, and, in, and our were the next most common (function) words. Then the word is as a verb appeared in rank 8.

Table6. The Word Frequency List of George W. Bush's Inaugural Addresses (1 100)

\begin{tabular}{|c|c|c|c|c|c|c|c|c|c|c|c|}
\hline Rank & Word & Freq. & Rank & Word & Freq. & Rank & Word & Freq. & Rank & Word & Freq. \\
\hline 1 & the & 142 & 26 & nation & 11 & 51 & its & 6 & 76 & great & 4 \\
\hline 2 & of & 118 & 27 & every & 10 & 52 & justice & 6 & 77 & life & 4 \\
\hline 3 & and & 114 & 28 & their & 10 & 53 & know & 6 & 78 & make & 4 \\
\hline 4 & in & 54 & 29 & because & 10 & 54 & must & 6 & 79 & now & 4 \\
\hline 5 & our & 52 & 30 & country & 9 & 55 & people & 6 & 80 & some & 4 \\
\hline 6 & to & 40 & 31 & one & 9 & 56 & seen & 6 & 81 & States & 4 \\
\hline 7 & we & 39 & 32 & own & 9 & 57 & work & 6 & 82 & there & 4 \\
\hline 8 & is & 31 & 33 & with & 9 & 58 & at & 6 & 83 & United & 4 \\
\hline 9 & that & 28 & 34 & be & 9 & 59 & cause & 6 & 84 & us & 4 \\
\hline 10 & freedom & 27 & 35 & as & 8 & 60 & but & 5 & 85 & yet & 4 \\
\hline 11 & have & 26 & 36 & history & 8 & 61 & came & 5 & 86 & before & 4 \\
\hline 12 & by & 24 & 37 & when & 8 & 62 & has & 5 & 87 & find & 3 \\
\hline 13 & will & 23 & 38 & world & 8 & 63 & long & 5 & 88 & also & 3 \\
\hline 14 & America & 21 & 39 & Americans & 8 & 64 & $\mathrm{a}$ & 5 & 89 & always & 3 \\
\hline 15 & for & 19 & 40 & no & 8 & 65 & or & 5 & 90 & another & 3 \\
\hline 16 & on & 17 & 41 & free & 7 & 66 & rights & 5 & 91 & chosen & 3 \\
\hline 17 & it & 16 & 42 & from & 7 & 67 & those & 5 & 92 & Clinton & 3 \\
\hline 18 & this & 16 & 43 & president & 7 & 68 & tyranny & 5 & 93 & come & 3 \\
\hline 19 & I & 16 & 44 & time & 7 & 69 & which & 5 & 94 & defended & 3 \\
\hline 20 & liberty & 15 & 45 & who & 7 & 70 & an & 5 & 95 & determined & 3 \\
\hline 21 & not & 15 & 46 & can & 7 & 71 & character & 4 & 96 & did & 3 \\
\hline 22 & are & 14 & 47 & citizens & 7 & 72 & choice & 4 & 97 & dignity & 3 \\
\hline 23 & you & 12 & 48 & day & 6 & 73 & fellow & 4 & 98 & do & 3 \\
\hline 24 & your & 12 & 49 & hope & 6 & 74 & fire & 4 & 99 & enemies & 3 \\
\hline 25 & all & 12 & 50 & human & 6 & 75 & good & 4 & 100 & excuse & 3 \\
\hline
\end{tabular}

\section{DISCUSSION}


The current study used WordSmith Tools 5.0, a set of corpus running software, to analyze and compare the top 100 frequently occurring words on the word lists of inaugural speeches addressed by two former American presidents, Bill Clinton and George W. Bush, and to find out the consistent personality traits accordingly. From the results of Table 5 and Table 6, the following analyses and comparisons can be done.

From the use of $1^{\text {st }}$ person singular pronouns, my appeared eight times in Bill Clinton's inaugural addresses, and I occurred seven times. In George W. Bush's inaugural speeches, $I$ appeared 16 times. It seems that Bush was a little more personal than Clinton. In terms of the use of $1^{\text {st }}$ person plural pronouns, Clinton used we 63 times, our 74 times, and us 19 times. Bush used we 39 times, our 52 times, and us 4 times. Obviously, Clinton used much more $1^{\text {st }}$ person plural pronouns than Bush, and this suggests that Bush was more formal and distant than Clinton. Furthermore, you appeared eight times, and your occurred four times in Clinton's addresses. The same $2^{\text {nd }}$ person pronouns appeared 12 times respectively in Bush's speeches. This finding indicated that Bush seemed more aggressive and pointed than Clinton. Regarding the use of $3^{\text {rd }}$ person plural pronouns, their appeared four times in Clinton's addresses. The same word occurred 10 times in Bush's. It can thus be concluded that Bush was more social and Clinton.

From the use of the words addressed to the audience/nation, Americans, American, and America appeared 12, 5, and 25 times respectively in Clinton's addresses. In Bush's, Americans appeared only eight times and America 21 times. In addition, people, citizens, and promise were used 14, 4, and 4 times respectively in Clinton's speeches. In Bush's, people was mentioned six times and citizens seven times. These statistics suggest that Clinton talked more to the audience/nation than Bush.

The use of indefinite pronouns can also reveal something related to a speaker's personalities. In Clinton's inaugural addresses, he mentioned all 14 times, it 13 times, and those five times. In Bush's, he mentioned all 12 times, some four times, one nine times, it 16 times, and its six times. Apparently, Clinton was more concrete and less abstract than Bush. Moreover, based onthe data of Table 5 and Table 6, it can also be found that Bush used more verb types than Clinton. This tells us that Bush was more dynamic than Clinton.

Furthermore, the auxiliary verb will that indicates future tense was used eight times in Clinton's speeches and 23 times in Bush's. This indicates that Bush paid more attention to the future than Clinton. From the use of prepositions, Bush's addresses included more prepositions than Clinton's speeches did (Bush: 294 times; Clinton: 262 times), which denoted that Bush was more detailed than Clinton.

With respect to the use of negative words, not was mentioned 18 times in Clinton's addresses, and no was used seven times. The same words appeared 15 and 8 times respectively in Bush's speeches. The data suggest that Clinton censored himself a little more than Bush did. Quantifiers were used in Bush's inaugural addresses much more than those in Clinton's. For example, in Bush's speeches, all occurred 12 times, every 10 times, all 12 times, one nine times, no eight times, some four times, and another three times. In Clinton's, all appeared 14 times, more seven times, no seven times, each five times, less four times, and every three times. The statistics signifies that Bush was more specific. In 
addition, the two former American presidents' use of positive adjectives also tells that Clinton was a little more positive than Bush: great was mentioned five times and better four times in Clinton's addresses; in Bush's speeches, good occurred four times and great appeared four times as well.

\section{CONCLuSion}

To conclude, from the analyses and comparisons of the top 100 frequently used words on the word lists of inaugural speeches addressed by Bill Clinton and George W. Bush above, it can be concluded that Clinton was more concrete and positive, talked more to the audience/nation, and censored himself more; Bush was more personal, formal, distant, aggressive, pointed, social, dynamic, detailed, specific, and paid more attention to the future.

\section{REFERENCES}

[1] Hunston, S. (2002). Corpora in Applied Linguistics. Cambridge University Press.

[2] Biber, D., Conrad, S. and Reppen, R. (1998). Corpus Linguistics: Investigating Language Structure and Use. Cambridge University Press.

[3] Hung, M. \& Hung, Y. S. (2012). Essential Vocabulary (猫準大考: 高頻率單字). Lung Teng Publishing Co. (ISBN: 9789862175699)

[4] Schmitt, N. (2010). Researching vocabulary: A vocabulary research manual. Basingstoke: Palgrave Macmillan.

\section{AUTHOR'S BIOGRAPHIES}

Dr. Maosheng Hung received his M.A. and Ph.D. in TESL from the University of Kansas. Dr. Hung is currently teaching as an associate professor for the Department of English at Fuzhou University of International Studies and Trade in China. His research interests include second/foreign language acquisition, corpus linguistics, and teaching English pronunciation.

Citation: Dr. Maosheng Hung, "A Corpus-Based Study of Two Former American Presidents' Inaugural Addresses" International Journal on Studies in English Language and Literature (IJSELL), vol 8, no. 9, 2020, pp. 54-64. doi: https://doi.org/10.20431/2347-3134.0809005.

Copyright: (0) 2020 Authors. This is an open-access article distributed under the terms of the Creative Commons Attribution License, which permits unrestricted use, distribution, and reproduction in any medium, provided the original author and source are credited. 